\title{
editorial
}

\section{6 urban spaces: gender, genre, mediation}

\section{introduction}

Cities have long held the attention of artists, writers, designers and academics. Offering rich possibilities for imagining public life, identities, and the nature of social interaction, the urban has appeared in a startling variety of representational forms. But Henri Lefebvre's (1991) classic account of the city reminds us that urban space is not merely a neutral context for people and for urban structures. Instead, city space functions actively to influence socio-cultural processes, identities and, indeed, the ways in which the city itself is represented. This insight challenges accounts that posit representation or mediation as a form of simple mirroring, and it has led to productive conceptualisations of urban spaces as becomings, as possibilities, as shifting political formations. Furthermore, as feminist interventions such as those of Rosalyn Deutsche (1997) and Gillian Rose (1993) make clear, such accounts of spatiality are not as abstract and generalised as they may claim: they are freighted with their conditions of production and social positioning of the producers. How can we think, then, about the role of gender in mediating space and in mediating understandings of space? How can we imagine urban space otherwise?

This collection attempts to open up such questions through the focus on gender, genre and mediation. In broad conceptual terms, it asks how we make understandings of the city. More specifically, it asks how different genres, or modes of mediation, produce particular ways of conceptualising the city and enable certain possibilities for thinking about gender and sexuality. The keynote paper and five articles examine how accounts of personal experience, poetry, drama, oral narratives, prose, novels, and travelogues represent urban spaces from the late sixteenth to the twenty-first centuries. These historically specific modes of mediation produce not only different ways of imagining the city, but also different conceptual and sensory frameworks for experiencing the city. The articles 're-gender' and 're-sexualise' the dominant ways of theorising urban space by emphasising gendered and sexualised bodies and by challenging the ideal of the disembodied theorist who produces knowledge of the city.

Feminist work over the last decades has placed an emphasis on the fluid and contingent nature of gender as experiential category, as conceptual tool, as 
representational form, and as regulatory device. Gender has been reconceptualised as enmeshed with multiple social positionings - for example, age and ethnicity, sexuality and nationality - and it has been conceived as made and remade in ways that both constrain and enable. More recently, accounts of the city and urban spaces have paralleled this emphasis on process and contingency (see Amin and Thrift, 2002), and have reconceived the city's economics, infrastructures, populations, representations, and architecture as variable performative enactments. In these accounts, cities are as much an idea or an ideal as a concrete spatial context within which things happen; they are composed of not only bricks and financial investment, but of imaginaries, sensory investments and representational formations (see Pile, 2005).

While there is a rather hesitant recognition of 'difference' in many such accounts, there is little sustained exploration of how social differences such as gender, sexuality and age inform the enactment of cities or the academic conceptualisation of cities. Indeed, the 'categories' of age and sexuality, as well as ethnicity and class, do not just 'cross-cut' gender; they intertwine in complex ways that are spatialised. Equally, these entanglements are temporalised - enacted and reformed in memory and in projecting thought forward or anticipating events to come. This intersectionality is highlighted in Janet Wolff's keynote piece, 'Unmapped spaces: gender, generation and the city', which underpins the collection. By exploring the ways in which certain bodies act as 'ghosts' which haunt conceptual framings of the city, Wolff suggests that older women's social invisibility in urban space may offer certain freedoms as they are less subject to forms of regulation. Nevertheless, these possibilities are gained at the expense of being framed as desexualised and these subjects' invisibility is compounded by academic analyses' tendency to exclude older people from the conceptual frameworks they deploy: they are literally written out of the urban script.

If Wolff's personal account of moving through urban space shows how ageing women can be rendered invisible, the subsequent essays show how other forms of representation foreground the complex relationships between bodies and urban environments. Helen Wilcox's discussion in "Ah, Famous Citie": Women, Writing, and Early Modern London' examines a range of urban perspectives. To be sure, as Wilcox explains, responses to England's metropolis were as extensive as its inhabitants. However, Isabella Whitney's late-sixteenth-century poem, 'Wyll and Testament', is noteworthy for the author's lowly status. Unlike the majority of published women writers in this period, Whitney was a working class woman, and she presents a striking poetic vision of early-modern urban space. In particular, she observes the female fruit-sellers who sat near the city gates, 'such as come in and out'. Thus, Whitney's poem implicitly reminds us of the city's porosity. By contrast, Wilcox examines how Jonathan Swift's satire 'A Beautiful Young Nymph Going to Bed' fashions both female identity and the city as 'painful deception[s]'. In Alison Findlay's essay, 'Playing For All in the 
City: Women's Drama', Swift's misogynistic, hierarchised tropes are dramatised on the Restoration stage in the figure of the female whore who mediates between the city and the countryside through the idea of dirt. However, as Findlay argues, developments in the theatre scene after the Great Fire of London in 1666 offered new possibilities to female playwrights and actresses. Playwrights such as Elizabeth Polwhele, Aphra Behn and Susannah Centlivre played with gender as appearance and produced new scripts for women to imagine the public spaces of London. In 'Queer Sex in the Metropolis? Place, Subjectivity and the Second World War', Emma Vickers takes London as her starting point to examine how the exigencies of the Second World War, and what the authorities chose 'not to see', enabled new sexual possibilities for gay men serving in the armed forces. Urban bars and clubs as well as transitory spaces of trucks and trains offered potential for these men to evade surveillance while simultaneously making their identities as gay men visible.

Janke Klok's argument in 'Revolutionary Voices: Nordic Women Writers and the Development of Female Urban Prose 1869-1900', as its title suggests, focuses on the neglected topic of female urban prose and the specific ways in which two nineteenth-century Norwegian writers, Camilla Collett and Amelie Skram, challenge prevailing orthodoxies of gender and genre. Whereas Collett's letters render a city such as Berlin as 'small and transparent', Skram's novels depict dark, stifling urban environments. Yet both women construct and contest normative formations of the city. If these foregoing essays examine the undulating surfaces of the city, Zoë Skoulding's piece, 'Alice Notley's Disobedient Cities', analyses how the twenty-first century American poet works with the idea of underground urban spaces and examines the tenuous and shifting capacity of language to bring to legibility certain lives and gendered bodies.

Elizabeth Grosz's work on 'Bodies-Cities' has famously attempted to question the opposition between the inside and the outside:

$[B] y$ looking at the outside of the body from the point of view of the inside, and looking at the inside of the body from the point of view of the outside. The body ... is not distinct from the city for they are mutually defining ... But it is not a mirroring of nature in artifice: rather there is a two-way linkage that could be defined as an interface. What I am suggesting is a model of the relations between bodies and cities that sees them, not as megalithic total entities, but as assemblages or collections of parts, capable of crossing the thresholds between substances to form linkages, machines, provisional and often temporary sub- or micro- groupings. It is not a holistic view, one that would stress the unity and integration of city and body, their 'ecological balance'. Rather, their interrelations involve a fundamentally disunified series of systems, a series of disparate flows, energies, events, or entities, bringing together or drawing apart their more or less temporary alignments. (Grosz, 1995: 104, 108)

By way of Grosz's theoretical paradigms, Skoulding illuminates some of the ways in which Notley's texts configure the unstable boundaries between body, city and text. However, in rethinking urban spaces, each essay in this special issue 
makes clear the importance of recognising the specificities of location - both locations in a city and how 'the city' is located in relation to other zones, for example the countryside (Findlay), the imaginary underground city (Skoulding), or the complex 'Citizen City' of the Norwegian bourgeoisie (Klok). Equally important is the emphasis on movement and relationality. Wilcox shows how Mary Carleton's coach offered a secure means by which she could travel around seventeenth-century London. By contrast, Vickers explores modes of transport (trucks, trains) that function as transitory, transgressive spaces. And, as Klok reminds us, travelling to other cities offers the space to imagine how our home cities might be otherwise.

Framed by Wolff's reflections on feminist thinking, then, this special issue examines the complexities and contradictions of exploring gender and the city. With a focus on process, performance and re-making - and an attention to the openness of these remakings - the authors analyse the ways in which different genres offer a range of entry points for understanding these complexities. This openness is a source of possibility: the space of the city, both lived and imagined from afar, is important for the formation of gender and sexual identities. Re-imaginings of the city by early modern female poets and playwrights wrought new possibilities for women in cities (Wilcox and Findlay) and in the Second World War, as Vickers explains, 'cities granted a multitude of homosocial spaces' which are revisited and reformed in memory and retelling. The complex literary space of the twentieth-century poem allows new ways of thinking about the city (Skoulding), and how gender is a work of both representation and spatialisation that is neither fixed nor ever 'complete'.

\section{acknowledgements}

The articles in this special issue emerged from a conference called 'City and Countryside: Gender and the Practice of Urban Culture' at the University of Groningen, the Netherlands. This conference was organised by Anne Cronin (Lancaster University) and Judith Vega (Department of Philosophy, University of Groningen), and was part of a collaboration between Lancaster University and the University of Groningen involving two other conferences on the theme of Gender in Cultural Practice. ('Sacred and Profane', 'Home and Memory')

Anne M. Cronin and Liz Oakley-Brown

\section{authors' biographies}

Anne M. Cronin is Senior Lecturer in the Sociology Department at Lancaster University, UK. She has published Advertising, Commercial Spaces and the Urban 
(2010), Advertising Myths (2004), Advertising and Consumer Citizenship (2000) and Consuming the Entrepreneurial City (2008, edited with K. Hetherington).

Liz Oakley-Brown is Lecturer in Renaissance literature in the Department of English and Creative Writing at Lancaster University, UK. She has published Ovid and the Cultural Politics of Translation in Early Modern England (2006), Translation and Nation: Towards a Cultural Politics of Englishness (2001, edited with R. Ellis) and The Rituals and Rhetoric of Queenship: Medieval to Early Modern (2009, edited with L.J. Wilkinson).

\section{references}

Amin, A. and Thrift, N. (2002) Cities: Reimagining the Urban, Cambridge: Polity.

Deutsche, R. (1997) Evictions: Art and Spatial Politics, Cambridge, MA: Graham Foundation/MIT Press.

Grosz, $\boldsymbol{\varepsilon}$. (1995) Space, Time and Perversion: Essays on the Politics of Bodies, London and New York: Routledge.

Lefebvre, H. (1991) The Production of Space, Nicholson-Smith, D. (1991) translator, Oxford: Blackwell.

Pile, S. (2005) Real Cities, London, Thousand Oaks, CA and New Delhi: Sage.

Rose, G. (1993) Feminism and Geography, Cambridge: Polity Press.

doi: $10.1057 / f r .2010 .21$ 